\title{
UNIVERSITYOF
}

FORWARD

THINKING

WESTMINSTER用

WestminsterResearch

http://www.westminster.ac.uk/westminsterresearch

\section{Evidence and Variation of Confiscation Orders: R v O'Flaherty (Carl Anthony) (Court of Appeal Criminal Division, 29th of} October 2018)

Singh, $C$.

This is a copy of the final version of an article published in International Commentary on Evidence, 15 (1), p. 20180004.

It is available from the publisher at:

https://dx.doi.org/10.1515/ice-2018-0004

The WestminsterResearch online digital archive at the University of Westminster aims to make the research output of the University available to a wider audience. Copyright and Moral Rights remain with the authors and/or copyright owners.

Whilst further distribution of specific materials from within this archive is forbidden, you may freely distribute the URL of WestminsterResearch: ((http://westminsterresearch.wmin.ac.uk/)).

In case of abuse or copyright appearing without permission e-mail repository@westminster.ac.uk 


\title{
Case Note and Analysis \\ Dr. Charanjit Singh ${ }^{1}$
}

\section{Evidence and Variation of Confiscation Orders: $R$ v O'Flaherty (Carl Anthony) (Court of Appeal Criminal Division, 29th of October 2018)}

\section{Judge: Green LJ, Goose J and Judge Mark Brown}

${ }^{1}$ University of Westminster, London, United Kingdom of Great Britain and Northern Ireland, E-mail: doctor.csingh@gmail.com

\begin{abstract}
:
The appellant ( $\mathrm{O}^{\prime}$ Flaherty) $(\mathrm{O})$ was appealing against two confiscation orders. In short, this case demonstrates that a judge can increase the value of a confiscation order made pursuant to s. 22 of the Proceeds of Crime Act 2002 (POCA) where adequate evidence is presented. The increase resulted from the fact that the Crown had discovered a further asset (property) that could be realized. O contended that a third party had an interest in the property and the value of the confiscation orders should not be increased. After questioning $\mathrm{O}$ and the third party the judge concluded that O's claim was not made out and the judge had not erred.
\end{abstract}

Keywords: criminal procedure and evidence, confiscation orders, variation, money laundering, judicial duties and proceeds of crime

DOI: 10.1515/ice-2018-0004

\section{Facts}

The appellant ( $\mathrm{O}^{\prime}$ Flaherty, from here $\mathrm{O}$ ) was appealing against the amount in two confiscation orders. ${ }^{1}$ In 2010 $\mathrm{O}$ had pleaded guilty to possession of criminal property and possession with intent to supply drugs contrary to the Misuse of Drugs Act 1971. Twenty small bags of cannabis had been recovered following the search of his vehicle. O was sentenced to a custodial sentence of fifty weeks, suspended for twelve months. He was ordered to pay $£ 5,135$ pursuant to a confiscation order under s. 6(5) of POCA 2002.

In $2013 \mathrm{O}$ was convicted of a conspiracy to commit a money laundering offence. In this instance $\mathrm{O}$ was sentenced to an eighteen-month custodial sentence and ordered to pay $£ 871$ pursuant to another confiscation order again under POCA 2002.

In both instances the benefit that $\mathrm{O}$ had received exceeded the amount recoverable pursuant to each confiscation order. O had satisfied both orders. Subsequently, the Crown had discovered another asset that could be realized in the form of a property owned by $\mathrm{O}$ and registered without encumbrance in his sole name at the Land Registry.

An application to reconsider the value of each confiscation order was made under s. 22 of the POCA 2002. ${ }^{2}$

$O$ contended that the property was purchased following a loan of $£ 30,000$ from his employer (A) on the premise that A would in return for the same receive a sum of $£ 40,000$. A contended, in his witness statement, that he had not registered his interest at the Land Registry. There was no evidence of the loan or the terms contended. Nor was there any evidence of the transaction ever having occurred. Finally, there was no evidence of the fact that $\mathrm{A}$ had ever employed $\mathrm{O}$ in any capacity i. e. there was a lack of records at Her Majesty's Revenue and Customs (HMRC) therefore there was no evidence to support this. However, there was evidence of a sum having been received by $\mathrm{O}$ in his bank account - information that was gaged from a mobile banking application on O's mobile telephone.

Given the facts as set out the judge proceeded to question both $\mathrm{O}$ and $\mathrm{A}$; concluding that $\mathrm{O}$ had failed to prove to the requisite evidential standard namely 'on the balance of probabilities'. There was a lack of evidence to prove $\mathrm{A}$ had lent $\mathrm{O}$ the money to purchase the property and therefore that $\mathrm{A}$ had an interest in it to the value of $£ 40,000$. The judge stated that $\mathrm{O}$ had not on the evidence; initially sought a mortgage to fund the purchase 
of the property and the transfer was simply a dishonest attempt and arrangement to frustrate the enforcement of the two confiscation orders. Therefore, the judge concluded that A had no interest in the property.

On appeal, $\mathrm{O}$ had contended bias on the part of the judge given the fact that both he and A had been crossexamined by the judge even though the Crown itself had not challenged the evidence. O contended that the findings made by the judge were not supported by the evidence and were manifestly unfair.

\section{Held: Appeal partly allowed}

Judges' sit to hear and determine issues and not to conduct investigations or inquiries on behalf of society in general. Therefore, the duty of the judge is to find the truth and do justice in accordance with the law. ${ }^{3}$ Judges should remember that the system in the United Kingdom was an adversarial one and not inquisitorial in nature ${ }^{4}$ even though they have been given case management powers under the Criminal Procedure Rules $2015 .^{5}$

The Court had determined three interventions that could lead to a successful appeal, ${ }^{6}$ namely:

- Inviting the jury to disbelieve the evidence presented by the defence which had been put to them in very strong terms;

- Where counsel had found it impossible to properly present a defence; and

- Where a defendant had been prevented from telling his side of the story.

It was highlighted that the list was not exhaustive and of course each case would be judged according to its own merits.

The judge had not erred by transgressing outside the limits of the jurisdiction conferred and no observer would conclude that there was bias. The case was not one that was before a jury and the judge was making findings of fact during the sentencing exercise. The Rules require judges to be proactive to ensure that justice is done. The questioning, not cross-examination, by the judge had carried a courteous tone and was not extensive. The judge was merely clarifying the facts set out by $\mathrm{O}$ in his witness statement. The facts presented raised a series of questions that needed to be answered even though, and the court did not understand why, the Crown had not challenged O's case. Once the questioning had been completed the judge asked O's counsel whether there were any more questions and thus any issue of unfairness would have been rectified at that stage.

The Court of Appeal did not make a finding that the judge had deviated outside his judicial function as to do so would have meant impeding the ability of a judge to enquire in a manner that is both fair and proportionate. The Crown was under a duty to test the evidence presented rigorously failing which a judge should not be prevented from continuing to carry out his or her duty. In the case, the judge had arrived at conclusions based on the evidence.

The Court of Appeal was of the same opinion that such a case as that presented was difficult to believe and had not been made out by the evidence. Factors that support this include the fact that (a) the loan was not in writing, (b) A had not registered his interest at the Land Registry, (c) no mortgage application and (d) why would A lend money to someone who had just been released from prison following a custodial sentence for money laundering. A also contradicted his own witness statement when he stated in relation to (d) that he was unaware of this fact. Thus, the evidence in this case had been implausible. The judge did not believe $\mathrm{O}$ and had been right to grant the application.

The appeal was partly allowed, namely that a variation to the confiscation orders should only be made to correct agreed mathematical errors.

\section{Notes}

1 Confiscation orders are made against a convicted defendant. They order him or her to pay an amount equal to the benefit derived from the crime. In contrast to a forfeiture order, a confiscation orders are not directed towards any particular assets.

2 Confiscation orders can be varied where new evidence comes to light within 28 days under the rule referred to as the 'slip rule'. After this period the Crown retains the right to apply for reconsideration if further evidence about a defendants assets is discovered. A court can review the order from the date of the conviction in terms of the amount of benefit for six years and indefinitely in respect of the amount available. For the variation procedure see: Criminal Procedure Rules Part 33.

3 Jones $v$ National Coal Board [1957] 2 QB 55

4 Barnard v DPP [2011] EWHC 1648

5 SI $2015 / 8490$

6 R v Jauvel (Jermaine) [2018] EWCA Crim 787 


\section{Bionotes}

Dr. Charanjit Singh is a widely published academic, a barrister and a Certified Civil and Commercial Mediator. He has built up extensive expertise in criminal evidence and his current research focuses on biometric and forensic evidence, terrorism and serious and organised criminality, and employment law. Direct contact can be made on: Doctor.CSingh@gmail.com. 